\title{
Physiological and physico-chemical changes in 1-methylcyclopropene-treated guava (Psidium guajava L. cv. Queso de Bola) fruit stored at ambient condition
}

\author{
${ }^{1,{ }^{*}}$ Zuniega, J.S. and ${ }^{1,2}$ Esguerra, E.B. \\ ${ }^{1}$ Postharvest and Seed Sciences Division, Institute of Crop Science, College of Agriculture and Food \\ Science (CAFS), University of the Philippines Los Baños (UPLB), College, Laguna 4031, Philippines; \\ ${ }^{2}$ Postharvest Horticulture Training and Research Center (PHTRC), CAFS, UPLB, College, Laguna 4031, \\ Philippines
}

\begin{abstract}
Article history:
Received: 25 May 2020

Received in revised form: 17

July 2020

Accepted: 9 August 2020

Available Online: 22

September 2020
\end{abstract}

\section{Keywords:}

Guava,

1-methylcyclopropene,

Ambient condition

DOI:

https://doi.org/10.26656/fr.2017.4(6).252

\begin{abstract}
The marketability of guava fruit is influenced by its quality attributes desired by consumers such as crispiness and crunchiness, green peel color, absence of defects, and better taste. 'Queso de Bola' guava fruits were treated with $600 \mathrm{~nL} \mathrm{~L}^{-1}$ of 1methylcyclopropane (1-MCP) for $12 \mathrm{hrs}$ then stored at ambient condition $\left(29 \pm 2^{\circ} \mathrm{C}, 60\right.$ $80 \% \mathrm{RH})$. Reduced respiration rate with 1 -MCP treatment was observed only starting on the $5^{\text {th }}$ day of storage. Ethylene production, however, was not suppressed. The continuous decline in polygalacturonase activity with $1-\mathrm{MCP}$ treatment coincided with firmness retention of the fruit until the $15^{\text {th }}$ day. Higher firmness of 1-MCP-treated fruits than control fruits was further supported by higher sensory scores for crispiness and crunchiness particularly towards the later part of storage. 1-MCP treatment did not prevent peel browning as shown by similar polyphenol oxidase activity and pattern of change in total phenolic content. Total soluble solids, titratable acidity, and $\mathrm{pH}$ were not affected by 1-MCP treatment and did not markedly change during storage. Ascorbic acid content decreased in both treatments until day 6 followed by a slight increase with 1-MCP treatment exhibiting higher levels than the control. In general, 1-MCP treatment prolonged the marketability of guava by 3-4 days which was attributed to the maintenance of firmness, retention of green peel color, and reduced disease incidence.
\end{abstract}

\section{Introduction}

Guava (Psidium guajava L.) is commercially cultivated in tropical and subtropical countries. The fruit is characterized by thick, white or pink and crispy flesh with slight sweet to bland taste. In the Philippines, 'Queso de Bola' is one of the locally-grown guava varieties and is popularly known as "guapple". It is considered as one of the emerging underutilized fruits with a huge potential as fresh and processed products both for local and export market due to its nutraceutical values (Gill, 2016; Mamede et al., 2016).

Guava is highly perishable with a shelf-life of six days at ambient condition when harvested at the green mature stage (Azzolini et al., 2005). For fresh consumption, 'Queso de Bola' guava is most desirable at the green and firm unripe stage with a crispy flesh. After harvest, the fruit ripens fast turning the crisp flesh into a soft one. Associated with ripening is the development of the distinct guava aroma (Gill, 2016) that is not desirable to the Filipino consumers. Moreover, the fruit also becomes readily susceptible to decay and peel browning.

There are several techniques to delay the ripening of fruits like low temperature storage and atmosphere modification. However, guava is susceptible to chilling injury (Singh and Pal, 2008) and cold storage facilities are not readily available in developing countries. Low temperature storage in combination with modified atmosphere packaging (MAP) can keep the fruit for about 2-3 weeks (Mitra et al., 2012). The problem with MAP, however, is the fast development of decay due to high relative humidity within the pack. Given the limitations of the aforementioned techniques, 1methylcyclopropene (1-MCP) is a potential treatment to extend the marketability of fresh fruit even under ambient condition (Lurie, 2007). Watkins (2008) further reported that the full benefits of 1-MCP maybe perceptible only under the abusive condition of high temperature which exists in the tropics and where retail marketing of guava fruits is usually under these 
conditions. 1-MCP inhibits ethylene perception by competitively and irreversibly binding to ethylene receptors (Sisler and Serek, 2003) thus preventing ethylene-dependent responses such as softening, volatile production, and pigment changes (Huber, 2008). As an ethylene antagonist, 1-MCP has been extensively used in apples (Watkins and Nock, 2012) and pear (Liu et al., 2013), two crops wherein retention of firmness is desired. Favorable responses have been reported also for climacteric fruits like banana (Zhu et al., 2015), avocado and mango (Hofman et al., 2001), durian (Amornputti et al., 2014) and papaya (Manenoi et al., 2007). In guava, 1 -MCP delayed fruit softening, retarded peel color change, inhibited respiration and ethylene production resulting in prolonged storage life (Singh and Pal, 2008).

This study aimed to determine the physiological and physico-chemical changes of 'Queso de Bola' guava fruit subjected to optimized 1-MCP treatment then stored at ambient condition $\left(29 \pm 2^{\circ} \mathrm{C}, 60-80 \% \mathrm{RH}\right)$.

\section{Materials and methods}

\subsection{Source and preparation of guava fruit}

Mature, defect-free, and medium-sized (400-800 g) guava fruits were harvested at approximately 120 days from anthesis in Lomboy Farm, an orchard in Guimba, Nueva Ecija which is located in the central part of Luzon, Philippines. Fruits were individually wrapped in polystyrene fruit cups, packed in plastic crates lined with newspaper, and transported by land to the Postharvest Horticulture Training and Research Center (PHTRC) at UP Los Baños. Upon arrival in the laboratory, fruits were again sorted as to freedom from mechanical damage which might have been incurred during field handling and transport. Prior to 1-MCP treatment, the fruits were dipped in $125 \mu \mathrm{L} \mathrm{L}^{-1}$ Amistar (a.i., azoxystrobin) for disease control and then air-dried.

\subsection{1-Methylcyclopropene treatment}

The preliminary study on optimization of $1-\mathrm{MCP}$ concentration and exposure duration indicated that 1MCP treatment at $600 \mathrm{~nL} \mathrm{~L}^{-1}$ for $12 \mathrm{hr}$ was the most effective combination in maintaining the desirable quality attributes of guava at ambient condition (data not shown), hence this was the concentration used in the present study.

Fruits were placed in treatment chamber (24-L plastic container) with an amber bottle containing a preweighed amount of 1-MCP inside. Following the manufacturer's recommendation, $2 \mathrm{~mL}$ distilled water was added to the 1-MCP powder to release the gas and the chamber was immediately closed. The headspace gas inside the treatment chambers was homogenized at regular time interval during 1-MCP treatment.

Before opening the treatment chambers, gases were withdrawn for measurement of the changes in $\mathrm{CO}_{2}$ and $\mathrm{O}_{2}$ concentrations after the 12-hour 1-MCP exposure. Headspace gases were measured using a gas chromatograph (GC). The treatment chambers were then opened and guava fruits were packed in corrugated cartons and kept at ambient condition until the fruits reached visual quality rating (VQR) of 5 (fair, defects moderate; limit of marketability).

\subsection{Respiration rate and ethylene production}

Respiration rate and ethylene production were determined using the static system. Three fruits per treatment were placed individually in respiratory glass jars with one fruit in a jar and then sealed for one hour. Duplicate headspace gas samples of $1-\mathrm{mL}$ each were withdrawn using an air-tight syringe at the time of enclosure (at $0 \mathrm{hr}$ ) and after $1 \mathrm{hr}$. $\mathrm{CO}_{2}$ production was measured using a GC (Shimadzu GC-2014; Kyoto, Japan) equipped with thermal conductivity detector (TCD) and Porapak QS column set at $100^{\circ} \mathrm{C}$ and $\mathrm{N}_{2}$ as the carrier gas. For ethylene production, gas sample was injected to gas chromatograph (Shimadzu GC-2014; Kyoto, Japan) with Porapak QS column set at $100^{\circ} \mathrm{C}$ and equipped with flame ionization detector (FID).

\subsection{Fruit quality assessment}

The changes in visual quality, peel color, peel browning, weight loss, disease incidence and severity were evaluated every other day during storage at ambient condition. For visual quality assessment, defects that occur after harvest such as shriveling, disease, and peel discoloration were considered and the following rating was used: 9-8 $=$ excellent, field fresh, 7-6 = good, defects minor, $5-4=$ fair, defects moderate, limit of marketability, 3 = poor, defects serious, $2=$ limit of edibility, and $1=$ non-edible under usual conditions. The change in peel color was determined by taking $L^{*}, a^{*}$, and $b^{*}$ readings on opposite sides along the equatorial region of the fruit using Konica Minolta Color Reader (CR10). Peel browning and disease severity were rated based on fruit area discoloration or infection, respectively, using the following rating: $1=$ none, $2=1$ $10 \%, 3=11-25 \%, 4=26-50 \%$, and $5=>50 \%$.

\subsection{Physico-chemical changes evaluation}

Subjective firmness was measured every other day through finger feel method using the following index: 5 = very firm, $4=$ firm, $3=$ yielding, $2=$ soft, and $1=$ very soft. Objective firmness determination was also done every three days. Fruit firmness was measured on opposite sides along the equatorial region of the 
unpeeled fruit using an Aikoh Digital Force Gauge penetrometer.

Weight loss of eight fruits per replicate was determined by obtaining the difference between the initial weight and weight at a specific time and then divided it by the initial weight. Weight loss was expressed in percent to reflect the cumulative change over time.

For total soluble solids (TSS) and titratable acidity (TA) determination, $50 \mathrm{~g}$ of the mid-portion of the fleshy pulp was homogenized with $50 \mathrm{~mL}$ distilled water for 2 min then filtered with small wad of cotton. TSS content was measured using Atago PAL-1 digital handheld refractometer while TA was measured by titrating a 2$\mathrm{mL}$ aliquot by a standard base $(0.1 \mathrm{~N} \mathrm{NaOH})$.

\subsection{Ascorbic acid content}

Ascorbic acid content was determined using the 2,6dichlorophenol indophenol titration method as described by Ranganna (1986). Standardization was done by titrating $25 \mathrm{mg}$ ascorbic acid solution dissolved in 100 $\mathrm{mL} 0.4 \%$ oxalic acid. Mixed sample of $50 \mathrm{~g}$ of sliced fruits and an equal amount of distilled water was homogenized for 2 mins and centrifuged at $8,000 \mathrm{rpm}$ for $10 \mathrm{~min}$ at $10^{\circ} \mathrm{C}$ using Thermal Scientific Sorval ST40R Centrifuge. A $2 \mathrm{~mL}$ aliquot from the homogenized mixture was diluted to $10 \mathrm{~mL}$ with $0.4 \%$ oxalic acid solution then titrated using $0.04 \%$ aqueous indophenol solution. Vitamin C content was reported as mg ascorbic acid per $100 \mathrm{~g}$ of fruit pulp.

\subsection{Polygalacturonase activity}

Activity of polygalacturonase (PG) was determined viscosimetrically using the modified method of Chan et al. (1981). Ten grams of fruit was homogenized in 30 $\mathrm{mL}$ of $1 \mathrm{M} \mathrm{NaCl}$ solution for $2 \mathrm{~min}$ and centrifuged at $8,000 \mathrm{rpm}$ for $10 \mathrm{mins}$ at $5^{\circ} \mathrm{C}$ using Thermal Scientific Sorval ST40R Centrifuge. After filtering through a small wad of cotton, $5 \mathrm{~mL}$ of the extract was added to $10 \mathrm{~mL}$ $1 \%$ pectin (dissolved in $0.1 \mathrm{M}$ acetate buffer at $\mathrm{pH} 5.0$ ). After introducing into a $1-\mathrm{mL}$ pipet, the solution was immediately released measuring the time of the flow from top to bottom mark and measurement was repeated after $30 \mathrm{~min}$.

\subsection{Polyphenol oxidase activity}

Polyphenol oxidase (PPO) activity was assayed with cathecol as substrate according to the optimized procedure of Del Valle (1974). The assay was performed using $0.5 \mathrm{~mL}$ of $8 \mathrm{mM}$ cathecol and $1 \mathrm{~mL} 0.2 \mathrm{M}$ acetate buffer ( $\mathrm{pH}$ 5.2) solution added to the sample test tubes containing $0.1 \mathrm{~mL}$ of the enzyme extract. The increase in absorbance at $420 \mathrm{~nm}$ at $25^{\circ} \mathrm{C}$ was recorded within 5 min. One unit of enzyme activity was defined as the amount of enzyme that caused a change of 0.001 in absorbance per min.

\subsection{Total phenolic content}

Determination of total phenolic content (TPC) was based on the modified method of Turnos (1993). Ten grams of pulp were sliced thinly, extracted by boiling with $50 \mathrm{~mL} \mathrm{70 \%} \mathrm{ethanol,} \mathrm{homogenized} \mathrm{for} 2 \mathrm{mins}$, and centrifuged at $8,000 \mathrm{rpm}$ for $10 \mathrm{mins}$ at $10^{\circ} \mathrm{C}$ using Thermal Scientific Sorval ST40R Centrifuge. Distilled water $(0.9 \mathrm{~mL})$ and $0.25 \mathrm{~N}$ Folin-Ciocalteau reagent $(2.0$ $\mathrm{mL}$ ) was added to a $0.1 \mathrm{~mL}$ extract from the homogenate. The resulting solution was allowed to stand for 5 mins followed by the addition of $2 \mathrm{~mL}$ saturated sodium carbonate with slight agitation. After an hour, absorbance was measured at $760 \mathrm{~nm}$ using a Secomam UV spectrophotometer. TPC was standardized against gallic acid and expressed as $\mu \mathrm{g} \mathrm{g}^{-1}$ of gallic acid equivalent (GAE).

\subsection{Sensory evaluation}

Crispiness and crunchiness are some of the desirable textural attributes of guava. Guava slices of approximately $0.3 \mathrm{~cm}$ in thickness were subjected to sensory evaluation with 12 untrained panelists. Crispiness was rated using the following scale: $1=$ leathery, $3=$ neither, and $5=$ crispy. Crunchiness was rated as: $1=$ very soft, $2=$ soft, $3=$ neither, $4=$ crunchy, and $5=$ very crunchy. Overall acceptability was rated as follows: 1 = dislike extremely, 2 = dislike very much, 3 $=$ dislike moderately, $4=$ dislike slightly, $5=$ neither dislike or like, $6=$ like slightly, $7=$ like moderately, $8=$ like very much, and $9=$ like extremely.

\subsection{Experimental design}

The experiment was laid out in Completely Randomized Design (CRD) with two treatments in triplicate. Each replicate consisted of eight fruits. Parametric data were subjected to ANOVA using SAS version 9.1. Differences between treatment means were compared using LSD at 5\% level of significance. Nonparametric data were subjected to Kruskal-Wallis test.

\section{Results and discussion}

\subsection{Headspace gas levels in treatment chambers}

Headspace gas levels were measured to determine if the change in $\mathrm{O}_{2}$ and $\mathrm{CO}_{2}$ concentrations inside the treatment chamber will have an effect on the binding of 1 -MCP and if there will be a residual effect of the modification of atmosphere on subsequent physicochemical changes of the fruit. After $12 \mathrm{hrs}$ of exposure to 
1-MCP gas, the $\mathrm{CO}_{2}$ increased to $1.16-1.30 \%$ while $\mathrm{O}_{2}$ decreased to $12.21-13.93 \%$ in chambers with or without 1-MCP. Based on the results presented in the following discussions, these modifications in the gas levels did not affect the physical attributes of the fruit. Blankenship and Dole (2003) indicated that up to $10 \% \mathrm{CO}_{2}$ in the treatment chamber did not inhibit the binding effectiveness of 1-MCP in apples.

\subsection{Respiration rate and ethylene production}

Earlier reports indicated that 1-MCP treatment often results in suppressed or delayed respiratory climacteric and ethylene production (Blankenship and Dole, 2003; Watkins, 2008; Dang et al., 2017). In this study, respiration rate of 1-MCP-treated fruit was higher than the control during the first 3 days (Figure 1) followed by a sharp decline on the $5^{\text {th }}$ day. From this day onwards, suppressed respiration rate with 1-MCP treatment was observed except on the $15^{\text {th }}$ day when there was a sharp increase which was attributed to the onset of slight decay. Until the $13^{\text {th }}$ day at ambient condition, 1-MCPtreated guava fruits did not ripen and remained firm similar to the observed delayed ripening for 7 to 8 days of the climacteric type guava variety Ben Dov treated with $500 \mathrm{~nL} \mathrm{~L}^{-1} 1$-MCP (Porat et al., 2009). In the case of control fruits, the initially lower respiration rate started to increase and exhibited the typical climacteric pattern of respiration. An abrupt increase in respiration rate of the control fruits was observed after a week of storage which peaked at $28.71 \mathrm{mg} \mathrm{CO}_{2} \mathrm{~kg}^{-1} \mathrm{~h}^{-1}$ on the $9^{\text {th }}$ day which coincided with the sudden decline in firmness and peak activity of PG.

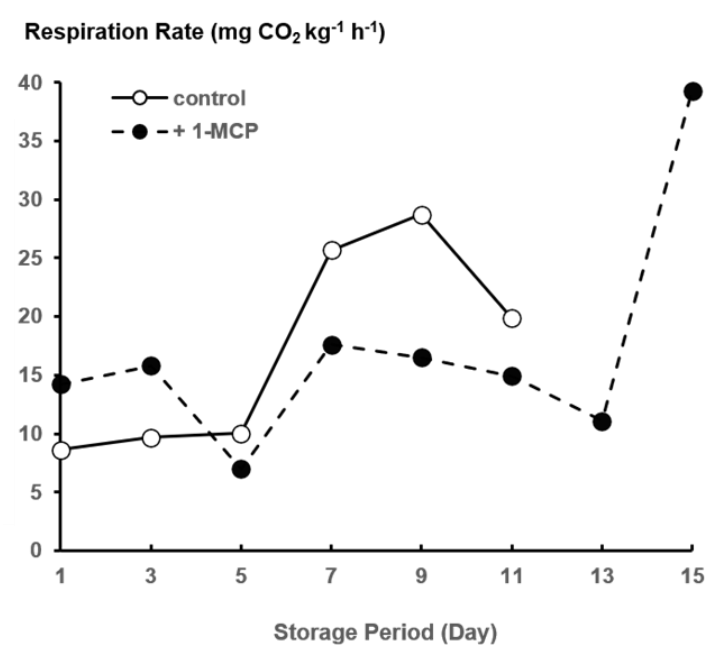

Figure 1. Respiration rate (mg $\mathrm{CO}_{2} \mathrm{~kg}^{-1} \mathrm{~h}^{-1}$ ) of 'Queso de Bola' guava fruits treated with $600 \mathrm{~nL} \mathrm{~L}^{-1} 1-\mathrm{MCP}$ for $12 \mathrm{hrs}$ and then stored at ambient condition $\left(29 \pm 2^{\circ} \mathrm{C}, 60-80 \% \mathrm{RH}\right)$. Each point represents the mean of three replicates

Ethylene production on the other hand, was not affected by 1-MCP treatment. A significant increase in ethylene production of the control fruit was observed only on the $3^{\text {rd }}$ day of storage reaching $0.25 \mathrm{~nL} \mathrm{~g}^{-1} \mathrm{~h}^{-1}$ while those of 1-MCP-treated fruits remained relatively stable until day 5 at $0.16 \mathrm{~nL} \mathrm{~g}^{-1} \mathrm{~h}^{-1}$ (Figure 2). On day 7, ethylene production of 1-MCP-treated fruits became higher than the control fruits which persisted until day 9 although differences were not significant. The increase in ethylene production of 1-MCP-treated fruits on the $13^{\text {th }}$ day was due to the onset of decay.

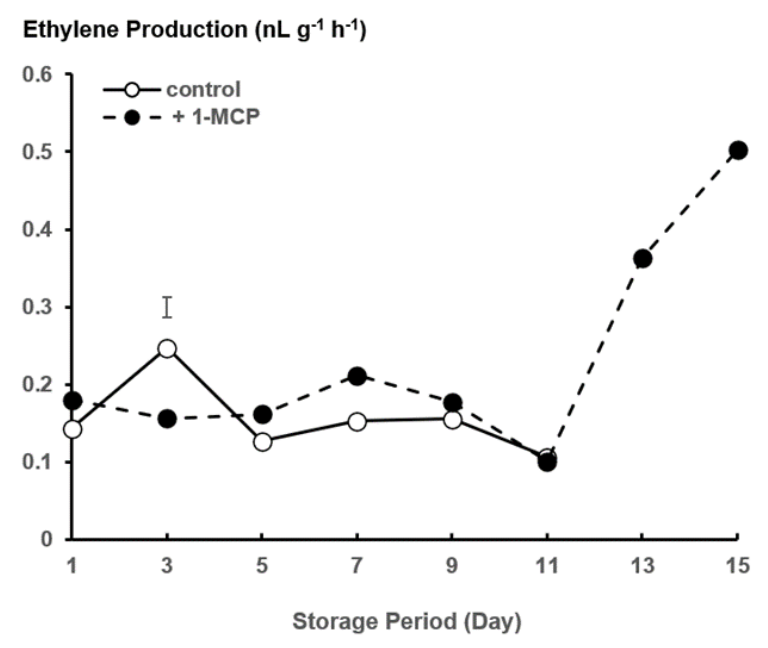

Figure 2. Ethylene production ( $\left.\mathrm{nL} \mathrm{g}^{-1} \mathrm{~h}^{1}\right)$ of 'Queso de Bola' guava fruits treated with $600 \mathrm{~nL} \mathrm{~L}^{-1} 1-\mathrm{MCP}$ for $12 \mathrm{hrs}$ and then stored at ambient condition $\left(29 \pm 2^{\circ} \mathrm{C}, 60-80 \% \mathrm{RH}\right)$. Vertical bar indicates LSD at 5\% level of significance. Each point represents the mean of three replicates

\subsection{Fruit firmness and polygalacturonase activity}

In this study, the prominent effect of 1-MCP was the retardation of the loss of firmness similar to the reports of Bassetto, Jacomino, Pinheiro et al. (2005) in 'Pedro Sato' guava. During storage at ambient condition, 1MCP-treated fruits were consistently firmer than control fruits (Figure 3A). On the $9^{\text {th }}$ day, 1-MCP-treated fruits were still firm while the control fruits were already yielding to slight finger pressure (rating of about 3.5). It took 13 days at ambient condition for 1-MCP-treated fruits to reach the same rating. Thus, with 1-MCP treatment, loss of firmness was delayed by 4 days.

The obtained subjective firmness values can be supported by the objective measurement of firmness using a penetrometer. During the first 6 days, control fruits were slightly firmer than the 1-MCP-treated fruits although differences were not significant (Figure 3B). On the $9^{\text {th }}$ day, however, firmness of control fruits sharply declined from $10.12 \mathrm{~N}$ to $6.48 \mathrm{~N}$ while that of the 1-MCP-treated fruits exhibited only a slight decline from $9.68 \mathrm{~N}$ to $9.19 \mathrm{~N}$. From then on, the decrease in firmness was slow. 1-MCP-treated fruits maintained high firmness values $(7.23 \mathrm{~N})$ for 15 days at ambient condition. It took only about 9 days for control fruits to reach almost the same firmness value. 


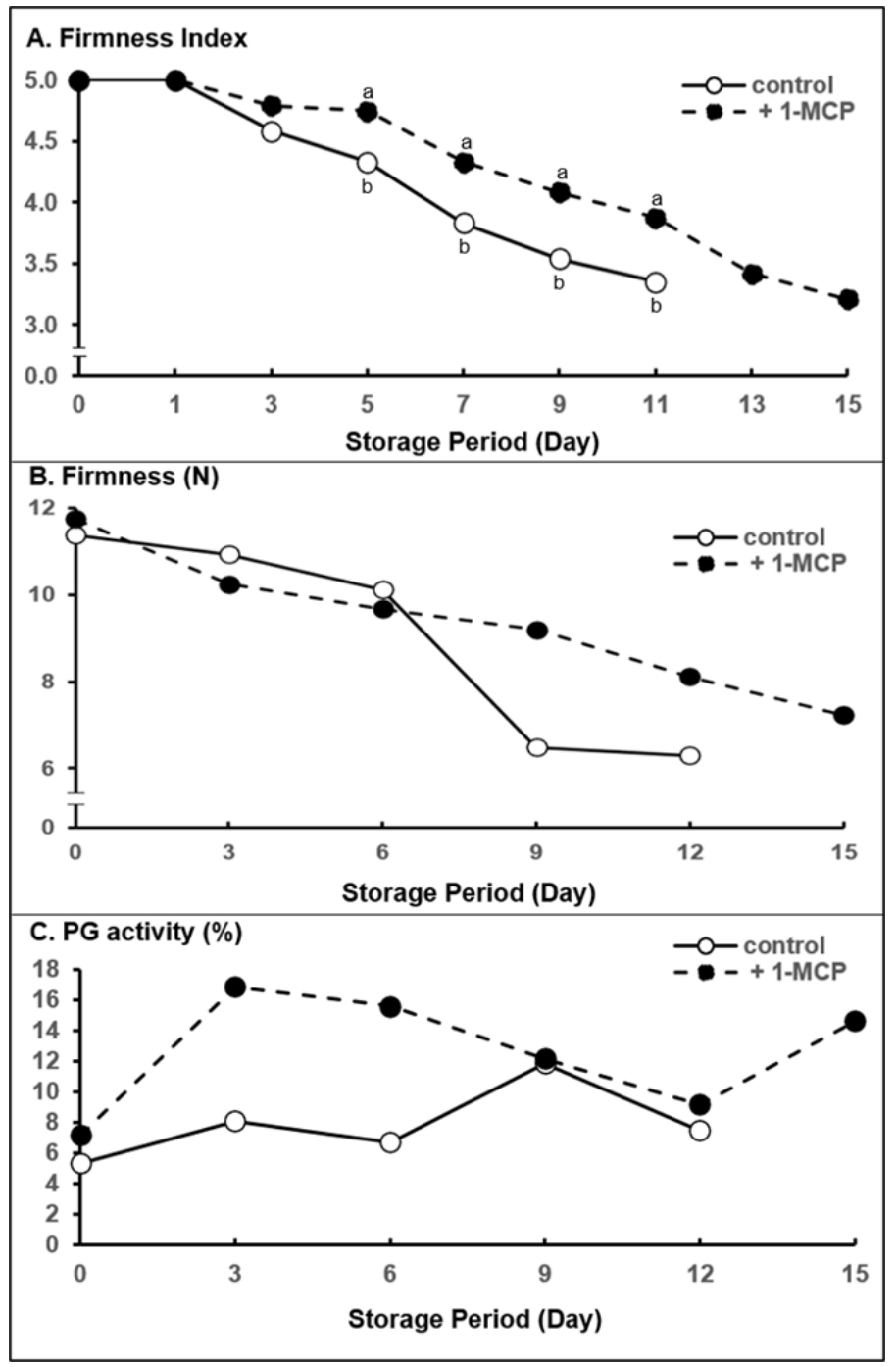

Figure 3. (A) Firmness index, (B) objective firmness (N), and (C) polygalacturonase activity (\%) of 'Queso de Bola' guava fruits treated with $600 \mathrm{~nL} \mathrm{~L}^{-1} 1-\mathrm{MCP}$ for $12 \mathrm{hrs}$ and then stored at ambient condition $\left(29 \pm 2^{\circ} \mathrm{C}, 60-80 \% \mathrm{RH}\right)$. Firmness index was analyzed using Kruskal-Wallis Test. For objective firmness and PG activity, each point represents the mean of three fruit samples during destructive sampling

Softening is characterized by progressive depolymerization of pectin and hemicelluloses, polysaccharides in the cell wall associated with the activity of hydrolytic enzymes such as pectin methyl esterase (PME) and polygalacturonase (PG) (Braga et al., 2018). Jain et al. (2003) reported that among the enzymes involved in textural changes of guava fruits, PG plays a major role and that PME plays a little role throughout ripening forming only pectic substances for PG. Moreover, Abu-Goukh and Bashir (2003) reported that white and pink-fleshed guava fruits had increased PG activity during ripening accompanied by a loss in flesh firmness. In this study, however, firmness of 1MCP-treated fruits was retained even with higher PG activity than control fruits. Compared with the control, however, PG activity of 1-MCP-treated fruits continuously decreased during storage which coincided with the retention of fruit firmness (Figure 3C). According to Ali et al. (2004), differential softening among tropical fruits cannot be attributed solely to either difference in the modification of cell wall pectin or to PG activity. The observed increase in PG activity on day 15 on the other hand, coincided with the stage when fruits already yielded to finger pressure.

\subsection{Peel Color}

Compared to the native Philippine guava, 'Queso de Bola' guava fruit does not change color from green to yellow but only from green to light yellow color. Thus, a non-destructive method was used in determining color change based on the International Commission on Illumination using a color meter that measures color space $L^{*}$ (lightness), $a^{*}$ (+ for red, - for green) and $b^{*}(+$ yellow, - blue) which gives less variable results and measures little differences (Barrett et al., 2010).

The brightness of peel color of 1-MCP-treated and control fruits decreased during storage as indicated by the decreasing $L^{*}$ values (Table 1 ). With regards to $a^{*}$ values, peel of control fruits was greener than 1-MCP treated fruits. However, the intensity of green color slowly decreased during storage as indicated by

Table 1. Peel color of 'Queso de Bola' guava fruits treated with $600 \mathrm{~nL} \mathrm{~L}{ }^{-1} 1-\mathrm{MCP}$ for 12 hrs and then stored at ambient condition $\left(29 \pm 2^{\circ} \mathrm{C}, 60-80 \% \mathrm{RH}\right)$

\begin{tabular}{ccccccc}
\hline \multirow{2}{*}{ Treatment } & \multicolumn{7}{c}{ Storage Period at Ambient (d) } \\
\cline { 2 - 7 } & 0 & 3 & 6 & 9 & 12 & 15 \\
\hline 1-MCP & $67.83 \mathrm{a}$ & $65.02 \mathrm{a}$ & $64.28 \mathrm{a}$ & $63.17 \mathrm{a}$ & $63.78 \mathrm{a}$ & 62.93 \\
Control & $67.02 \mathrm{a}$ & $64.83 \mathrm{a}$ & $64.47 \mathrm{a}$ & $63.90 \mathrm{a}$ & $63.13 \mathrm{a}$ & - \\
\hline \multicolumn{7}{c}{$a^{*}$} \\
\hline $1-\mathrm{MCP}$ & $-3.68 \mathrm{~b}$ & $-1.35 \mathrm{a}$ & $0.35 \mathrm{a}$ & $-0.03 \mathrm{a}$ & $1.55 \mathrm{a}$ & 1.17 \\
Control & $-2.00 \mathrm{a}$ & $-0.67 \mathrm{a}$ & $-0.07 \mathrm{a}$ & $0.20 \mathrm{a}$ & $-0.27 \mathrm{a}$ & - \\
\hline & \multicolumn{7}{c}{$b^{*}$} \\
\hline $1-M C P$ & $42.53 \mathrm{a}$ & $41.78 \mathrm{a}$ & $42.92 \mathrm{a}$ & $43.38 \mathrm{a}$ & $43.42 \mathrm{a}$ & 43.22 \\
Control & $41.90 \mathrm{a}$ & $40.65 \mathrm{a}$ & $42.62 \mathrm{a}$ & $41.15 \mathrm{a}$ & $43.12 \mathrm{a}$ & - \\
\hline
\end{tabular}

Means within columns for each color parameter followed by the same letter are not significantly different at 5\% level, LSD. Each data represents the mean of six readings taken from three replicates. No values were indicated on the $15^{\text {th }}$ day since the experiment was already terminated 
increasing $a^{*}$ values. 1-MCP-treated fruits had higher $b^{*}$ values than control fruits but differences were not significant. Regardless of treatment, guava fruits hardly exhibited loss of green color during storage.

\subsection{Visual quality}

Visual quality in this study refers to the external physical attributes of guava like the absence of defects (shriveling, disease) and discoloration like peel browning. Starting on the $3^{\text {rd }}$ day, visual quality rating declined abruptly with control fruits reaching the limit of marketability (VQR 5) on day 9 (Figure 4). On the other hand, 1-MCP-treated fruits were still marketable until day 12. The decline in VQR was due to disease (Figure 5) and peel browning (Figure 6A). Fruit shriveling was not apparent in both treatments until the $15^{\text {th }}$ day at ambient condition even with $14 \%$ weight loss.

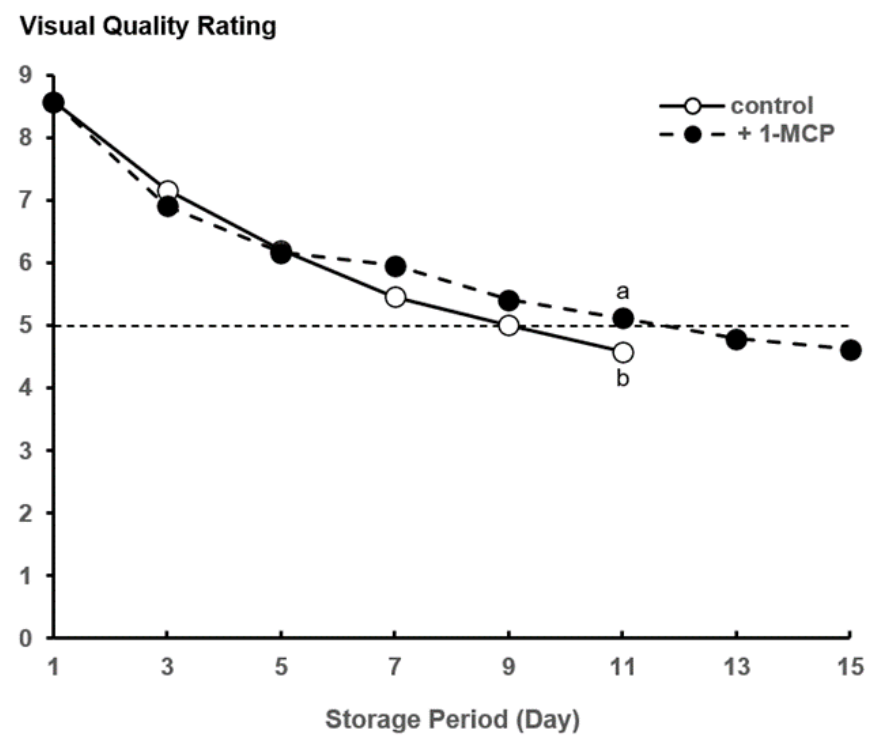

Figure 4. Visual quality rating of 'Queso de Bola' guava fruits treated with $600 \mathrm{~nL} \mathrm{~L}^{-1} 1-\mathrm{MCP}$ for $12 \mathrm{hrs}$ and then stored at ambient condition $\left(29 \pm 2{ }^{\circ} \mathrm{C}, 60-80 \% \mathrm{RH}\right)$. Data was analyzed using Kruskal-Wallis test. Horizontal dashed line indicates the limit of marketability

Observed symptoms of disease in guava fruits were similar to the reports of Magarro (2018) and Bendal (2010). There were soft, sunken and circular brown rot symptoms caused by Geotrichum sp., dry brown rot caused by Calonectria sp., and irregularly shaped brown soft rot caused by Lasiodiplodia sp. Manifestation of disease symptoms was delayed by about 5 days in 1MCP-treated fruits with less than 5\% infected fruits (Figure 5). There was also a slow rate of disease development in 1-MCP-treated fruits reaching only less than $10 \%$ on day 7 and $33.33 \%$ on the $13^{\text {th }}$ day until the end of storage. On the other hand, control fruits manifested disease symptoms as early as the $3^{\text {rd }}$ day of storage with $16.67 \%$ infected fruits. Disease incidence continued its fast increase on the $5^{\text {th }}$ day with $29.17 \%$ infected fruits. The occurrence of disease, however, in the control fruits did not progress beyond day 5 . Although disease incidence reached 30\%, the severity of infection was very slight with less than $10 \%$ of the fruit surface infected (severity rating of 1.5 ). The reduction in disease incidence and severity was also observed in 'Allahabad Safeda' guava fruits treated with 1-MCP which had four- to five-fold reduction in the incidence of decay caused by Rhizopus sp. (Singh and Pal, 2008).

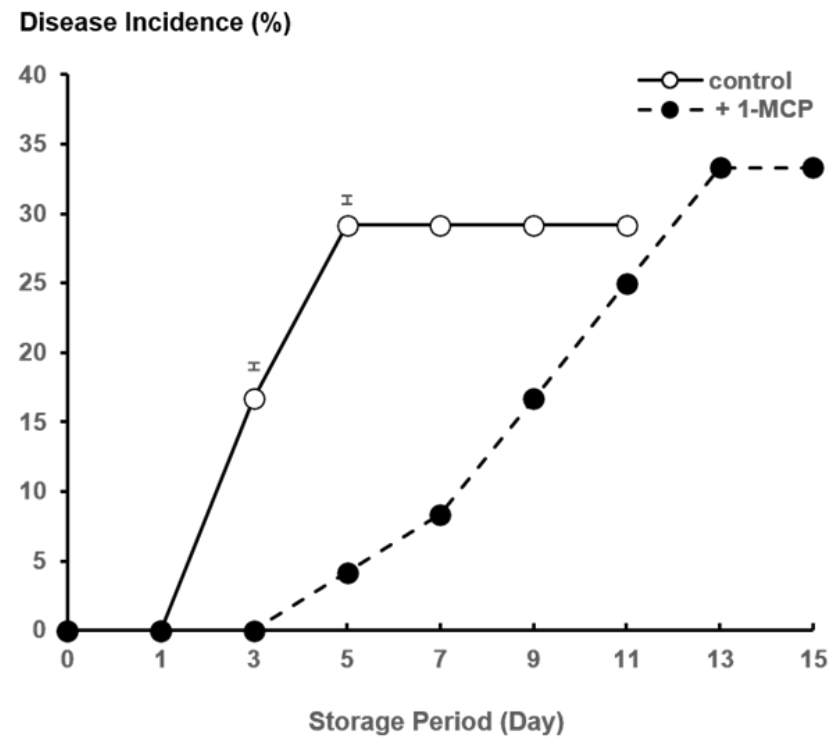

Figure 5. Disease incidence (\%) of 'Queso de Bola' guava fruits treated with $600 \mathrm{~nL} \mathrm{~L}^{-1} 1$-MCP for $12 \mathrm{hrs}$ and then stored at ambient condition $\left(29 \pm 2^{\circ} \mathrm{C}, 60-80 \% \mathrm{RH}\right)$. Bars indicate LSD at $5 \%$ level of significance. Each point represents the mean of three replicates consisting of eight fruits per replicate

\subsection{Peel browning, PPO activity, and total phenolic content}

Peel browning of guava fruits occurs even before harvest. Singh (2010) stated that guava fruits have delicate skin that is vulnerable to bruising and mechanical injuries. In this study, the decline in the visual quality of fruits was mainly due to browning. Even with increasing severity of peel browning during storage, the pulp of the fruits regardless of treatment maintained its white color. Some of the guava fruits regardless of treatment had already slight peel browning before 1-MCP treatment (Figure 6A). 1-MCP treatment did not reduce the incidence of peel browning in guava fruits. The rate of browning with respect to duration of storage was almost the same for both 1-MCP-treated and control fruits. As early as the $5^{\text {th }}$ day at ambient condition, fruits had moderate peel browning.

Browning results from cellular damage during enzymatic oxidation of phenolic compounds by PPO which are originally sequestered in different compartments (Wang et al., 2017). The occurrence of 
peel browning, however, cannot be related to the activity of PPO which is in contrast to the report of Zhang and Zhang (2008) in pomegranate peel. In 'Queso de Bola' guava fruits, PPO activity was relatively low in both treatments until the $9^{\text {th }}$ day of storage (Figure 6B). Initially, PPO activities after harvest in 1-MCP-treated and control fruits were 0.37 unit $\mathrm{mL}^{-1} \mathrm{~min}^{-1}$ and 0.38 unit $\mathrm{mL}^{-1} \mathrm{~min}^{-1}$, respectively and remained fairly stable until the $9^{\text {th }}$ day. The maximum activity of PPO in both treatments was observed on the $12^{\text {th }}$ day when fruits were showing moderate peel browning.
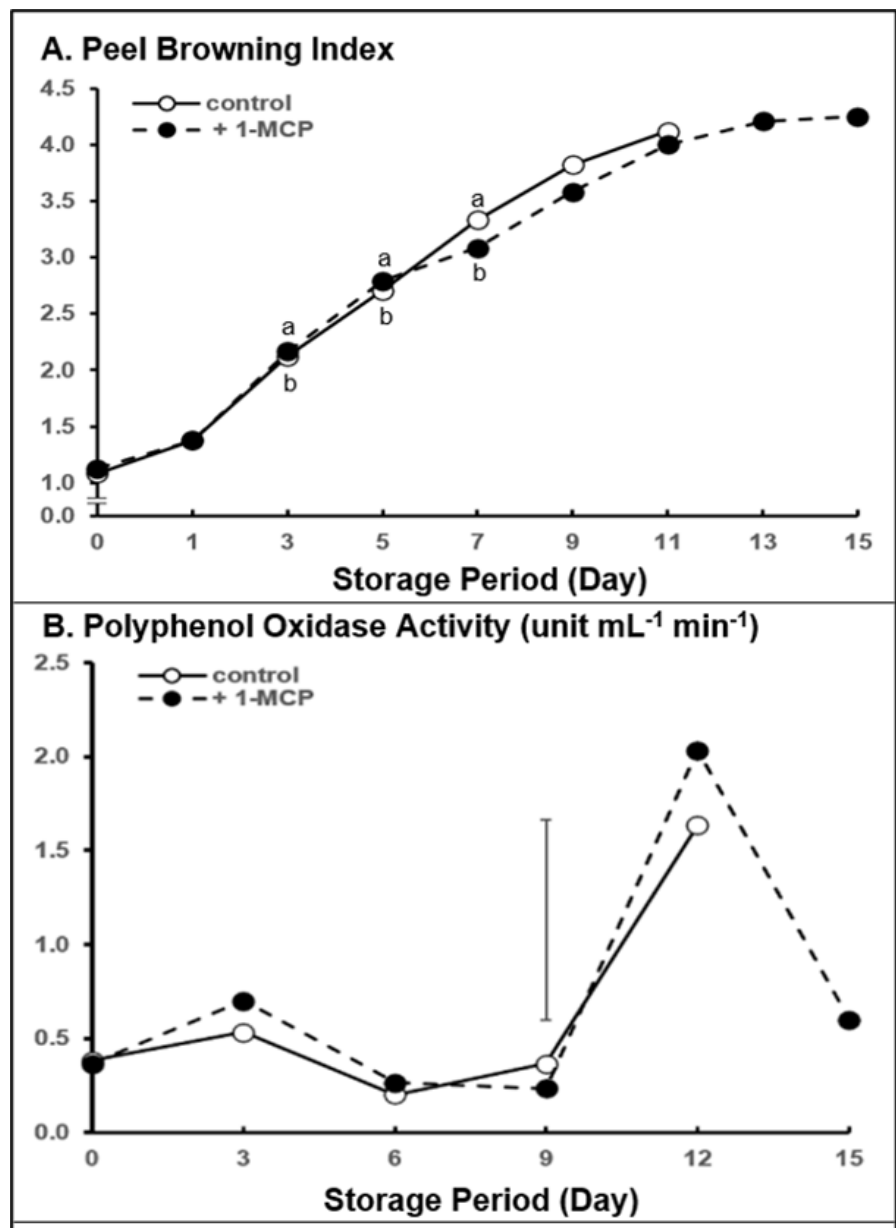

C. Total Phenolic Content ( $\left.\mu \mathrm{g} \mathrm{g}^{-1} \mathrm{GAE}\right)$

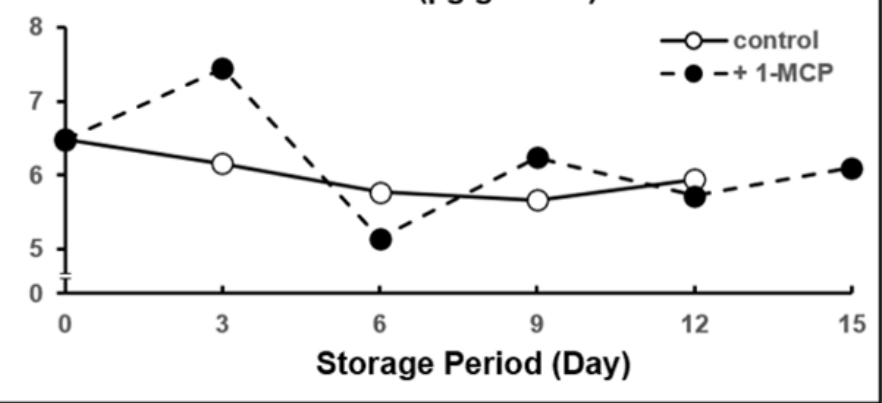

Figure 6. (A) Peel browning index, (B) polyphenol oxidase activity (enzyme unit $\mathrm{mL}^{-1} \mathrm{~min}^{-1}$ ), and (C) total phenolic content ( $\mu \mathrm{g} \mathrm{g}^{-1} \mathrm{GAE}$ ) of 'Queso de Bola' guava fruits treated with $600 \mathrm{~nL} \mathrm{~L}^{-1} 1-\mathrm{MCP}$ for $12 \mathrm{hrs}$ and then stored at ambient condition $\left(29 \pm 2^{\circ} \mathrm{C}, 60-80 \% \mathrm{RH}\right)$. Peel browning index was analyzed using Kruskal-Wallis test. For PPO and TPC, each point represents the mean of three fruit samples during destructive sampling. Bar indicates LSD at 5\% level of significance
With regard to total phenolic content (TPC), there was no definite pattern of change throughout storage of 1 -MCP-treated fruits (Figure 6C). The initially $6.49 \mu \mathrm{g} \mathrm{g}^{-1}$ GAE increased to $7.45 \mu \mathrm{g} \mathrm{g}^{-1}$ GAE on day 3 followed by an abrupt decrease on day 6 and then an increase which remained relatively stable at about $6.00 \mu \mathrm{g} \mathrm{g}^{-1} \mathrm{GAE}$ until day 15 . On the other hand, TPC of the control fruits was slowly decreasing until the $9^{\text {th }}$ day of storage from 6.48 $\mu \mathrm{g} \mathrm{g}^{-1} \mathrm{GAE}$ to $5.67 \mu \mathrm{g} \mathrm{g}^{-1} \mathrm{GAE}$ and slightly increased to $5.95 \mu \mathrm{g} \mathrm{g}^{-1} \mathrm{GAE}$ on the $12^{\text {th }}$ day when its maximum PPO activity was also observed.

\subsection{Total soluble solids, titratable acidity, and $\mathrm{pH}$}

Bassetto et al. (2005) reported that 1-MCP lowered the TSS values of 'Pedro Sato' guava fruits. Except at day 3, 1-MCP-treated fruits had also lower total soluble solids (TSS) values during storage than control fruits (Table 2) although differences were not significant. However, TSS values of all fruits did not markedly change during storage and ranged from 6.20 to $8.13^{\circ}$ Brix. This high TSS value was obtained in the control fruits that manifested a rapid decline in softening on day 9.

Titratable acidity (TA) values of fruits on the other hand, slightly increased in both treatments during storage (Table 2) which is similar to the report that 'Pedro Sato' guava treated with 1-MCP maintained higher acidity levels during storage (Bassetto et al., 2005). As in TSS, there was no significant difference in TA among fruits although 1-MCP-treated fruits had slightly higher TA values than the control.

Similar to TSS and TA, 1-MCP did not significantly affect the $\mathrm{pH}$ values of guava fruits.

\subsection{Ascorbic acid content}

Initially, control fruits had higher ascorbic acid content than 1-MCP-treated fruits (Table 2). During storage, however, 1-MCP-treated fruits maintained higher ascorbic acid content than control fruits starting on the $3^{\text {rd }}$ day until the last day of storage. In 1-MCPtreated fruits, the highest ascorbic acid content of 127.42 $\mathrm{mg} 100 \mathrm{~g}^{-1}$ was obtained on the last day of storage. Control fruits had low ascorbic acid content of $82.09 \mathrm{mg}$ $100 \mathrm{~g}^{-1}$ on the last day. Accordingly, ascorbic acid is responsible for the scavenging of the reactive oxygen species (Chiari et al., 2012) thus delaying senescence which in the case of guava manifests as peel browning. However, peel browning occurred in both 1-MCP-treated and control fruits. Thus, peel browning cannot be correlated to ascorbic acid content. 
Table 2. Physico-chemical changes of 'Queso de Bola' guava fruits treated with $600 \mathrm{~nL} \mathrm{~L}^{-1} 1-\mathrm{MCP}$ for 12 hrs and then stored at ambient condition $\left(29 \pm 2^{\circ} \mathrm{C}, 60-80 \% \mathrm{RH}\right)$

\begin{tabular}{ccccccc}
\hline \multirow{2}{*}{ Treatment } & 0 & \multicolumn{7}{c}{ Storage Period at Ambient $(\mathrm{d})$} \\
\cline { 2 - 7 } & 0 & 6 & 9 & 12 & 15 \\
\hline 1-MCP & $6.20 \mathrm{a}$ & $7.20 \mathrm{a}$ & $7.13 \mathrm{a}$ & $7.60 \mathrm{a}$ & $7.53 \mathrm{a}$ & 7.50 \\
Control & $6.26 \mathrm{a}$ & $7.07 \mathrm{a}$ & $7.53 \mathrm{a}$ & $8.13 \mathrm{a}$ & $7.83 \mathrm{a}$ & - \\
\hline \multicolumn{7}{c}{ TA $(\%)$} \\
\hline $1-\mathrm{MCP}$ & $0.17 \mathrm{a}$ & $0.17 \mathrm{a}$ & $0.19 \mathrm{a}$ & $0.22 \mathrm{a}$ & $0.16 \mathrm{a}$ & 0.27 \\
Control & $0.13 \mathrm{a}$ & $0.17 \mathrm{a}$ & $0.17 \mathrm{a}$ & $0.16 \mathrm{a}$ & $0.20 \mathrm{a}$ & - \\
\hline \multicolumn{7}{c}{$\mathrm{pH}$} \\
\hline $1-\mathrm{MCP}$ & $4.30 \mathrm{a}$ & $4.32 \mathrm{a}$ & $4.36 \mathrm{a}$ & $4.27 \mathrm{a}$ & $4.46 \mathrm{a}$ & 4.47 \\
Control & $4.34 \mathrm{a}$ & $4.35 \mathrm{a}$ & $4.17 \mathrm{~b}$ & $4.28 \mathrm{a}$ & $4.37 \mathrm{a}$ & - \\
\hline \multicolumn{7}{c}{ Ascorbic Acid (mg $\left.100 \mathrm{~g}^{-1}\right)$} \\
\hline 1-MCP & $101.84 \mathrm{a}$ & $121.95 \mathrm{a}$ & $95.62 \mathrm{a}$ & $122.35 \mathrm{a}$ & $115.50 \mathrm{a}$ & 127.42 \\
Control & $110.21 \mathrm{a}$ & $104.76 \mathrm{a}$ & $74.99 \mathrm{a}$ & $99.70 \mathrm{a}$ & $82.09 \mathrm{~b}$ & - \\
\hline
\end{tabular}

Means within columns for each parameter followed by the same letter are not significantly different at 5\% level, LSD. Each point represents the mean of three replicates. No values were indicated on the $15^{\text {th }}$ day since the experiment was already terminated

Table 3. Sensory characteristics of 'Queso de Bola' guava fruits treated with $600 \mathrm{~nL} \mathrm{~L}{ }^{-1} 1-\mathrm{MCP}$ for 12 hrs and then stored at ambient condition $\left(29 \pm 2{ }^{\circ} \mathrm{C}, 60-80 \% \mathrm{RH}\right)$

\begin{tabular}{ccccccc}
\hline \multirow{2}{*}{ Treatment } & \multicolumn{7}{c}{ Storage Period at Ambient (d) } \\
\cline { 2 - 7 } & 0 & 3 & 6 & 9 & 12 & 15 \\
\hline \multicolumn{7}{c}{ Crispiness } \\
\hline $1-\mathrm{MCP}$ & $4.17 \mathrm{a}$ & $4.08 \mathrm{a}$ & $3.92 \mathrm{a}$ & $3.25 \mathrm{a}$ & $3.75 \mathrm{a}$ & 3.75 \\
Control & $4.08 \mathrm{a}$ & $4.00 \mathrm{a}$ & $3.33 \mathrm{a}$ & $3.50 \mathrm{a}$ & $2.83 \mathrm{a}$ & - \\
\hline \multicolumn{7}{c}{ Crunchiness } \\
\hline $1-\mathrm{MCP}$ & $2.75 \mathrm{a}$ & $2.92 \mathrm{a}$ & $2.92 \mathrm{a}$ & $2.42 \mathrm{a}$ & $2.83 \mathrm{a}$ & 2.75 \\
Control & $2.92 \mathrm{a}$ & $3.33 \mathrm{a}$ & $2.67 \mathrm{a}$ & $2.92 \mathrm{a}$ & $2.00 \mathrm{~b}$ & - \\
\hline \multicolumn{7}{c}{ Overall Acceptability } \\
\hline $1-\mathrm{MCP}$ & $6.33 \mathrm{~b}$ & $6.83 \mathrm{a}$ & $6.83 \mathrm{a}$ & $6.42 \mathrm{a}$ & $6.83 \mathrm{a}$ & 6.67 \\
Control & $7.50 \mathrm{a}$ & $6.50 \mathrm{a}$ & $6.92 \mathrm{a}$ & $6.83 \mathrm{a}$ & $7.00 \mathrm{a}$ & - \\
\hline
\end{tabular}

Data was analyzed using the Kruskal-Wallis test. No values were indicated on the $15^{\text {th }}$ day since the experiment was already terminated

\subsection{Sensory evaluation}

Crispiness and crunchiness are some of the desired quality attributes of 'Queso de Bola' guava fruits. According to Chauvin et al. (2008), crispiness is defined as "one sound event perceived as a sharp, clean, fast, high pitched sound and evaluated with the incisors and lips open". On the other hand, crunchiness is a "multiple lower pitched sound perceived as a series of small events and evaluated with the molar and lips closed". Generally, crispiness of fruits decreased during storage at ambient condition regardless of the treatment (Table 3). 1-MCPtreated fruits were crispier than control fruits which were more notable on day 12. As to the crunchiness, fruits regardless of treatments were rated by the panelists as neither crunchy nor soft (rating of 2.42 to 3.33) throughout the evaluation period except for the soft texture observed in the control fruits on day 12 . Overall acceptability of fruits ranged from 6.33 to 7.50 (like slightly to like moderately) with the control fruits slightly preferred by the panelists than the 1-MCPtreated fruits.

\section{Conclusion}

1-MCP treatment at $600 \mathrm{~nL} \mathrm{~L}^{-1}$ for $12 \mathrm{hrs}$ prolonged the marketability of 'Queso de Bola' guava by 3-4 days longer than control fruits which were attributed to the maintenance of firmness, retention of green peel color, and reduced disease incidence.

1-MCP slowed down the decline in firmness thus maintaining the crisp texture desired by consumers. However, the relationship between retention of firmness and suppressed polygalacturonase activity and ethylene production brought about by 1-MCP treatment as reported in other studies was not established in this study.

\section{Acknowledgement}

The research work was funded by the Department of Agriculture-Bureau of Agricultural Research (DA-BAR) through the project entitled "Quality Systems Improvement of Dragon Fruit, Soursop and Apple Guava through Value Chain Analysis and Management". The 
authors would also like to thank the Mycology Laboratory of the Institute of Weed Science, Entomology, and Plant Pathology (IWEP), CAFS, UPLB for the identification of the causal organisms of the diseases.

\section{References}

Abu-Goukh, A.A. and Bashir, H.A. (2003). Changes in pectic enzymes and cellulase activity during guava fruit ripening. Food Chemistry, 83(2), 213-218. https://doi.org/10.1016/S0308-8146(03)00067-0

Ali, Z.M., Chin, L.H. and Lazan, H. (2004). A comparative study on wall degrading enzymes, pectin modifications and softening during ripening of selected tropical fruits. Plant Science, 167(2), 317 -327. https://doi.org/10.1016/j.plantsci.2004.03.030

Amornputti, S., Ketsa, S. and van Doorn, W.G. (2014). Effect of 1-methylcyclopropene (1-MCP) on storage life of durian fruit. Postharvest Biology and Technology, 97, 111-114. https://doi.org/10.1016/ j.postharvbio.2014.06.011

Azzolini, M., Jacomino, A.P., Bron I.U., Kluge, R.A. and Schiavinato, M.A. (2005). Ripening of 'Pedro Sato' guava: a study on its climacteric or nonclimacteric nature. Brazilian Journal of Plant Physiology, 17(3), 299-306. https://doi.org/10.1016/ j.postharvbio.2014.06.011

Barrett, D.M., Beaulieu, J.C. and Shewfelt, T.R. (2010). Color, flavor, texture, and nutritional quality of fresh -cut fruits and vegetables: desirable levels, instrumental and sensory measurement, and the effects of processing. Critical Reviews in Food Science and Nutrition, 50(5), 369-389. https:// doi.org/10.1080/10408391003626322

Bassetto, E., Jacomino, A.P. and Pinheiro, A.L. (2005). Conservation of 'Pedro Sato' guavas under treatment with 1-methylcyclopropene. Pesquisa Agropecuaria Brasiliera, 40(5), 433-440. https://doi.org/10.1590/ S0100-204X2005000500002

Bassetto, E., Jacomino, A.P., Pinheiro, A.L. and Kluge, R.A. (2005). Delay of ripening of 'Pedro Sato' guava with 1-methylcyclopropene. Postharvest Biology and Technology, 35(3), 303-308. https://doi.org/10.1016/ j.postharvbio.2004.08.003

Bendal, J.G.B. (2010). Identification and characterization of fungal pathogens causing diseases of guava (Psidium guajava L.) and efficacy test of selected fungicides. College, Laguna, Philippines: University of the Philippines Los Baños, BSc. Thesis.

Blankenship, S.M. and Dole, J.M. (2003). 1Methylcyclopropene: a review. Postharvest Biology and Technology, 28(1), 1-25. https://doi.org/10.1016/
S0925-5214(02)00246-6

Braga, M.A., Marques, T.R., Simao, A.A., Botelho, L.N.S., de Oliveira L.S. and de Abreu, C.M.P. (2018). Mechanism of firmness loss in guava cv. Pedro Sato during ripening at room temperature. Food Science and Technology (Campinas), 38(1), 26 -32. https://doi.org/10.1590/1678-457x.35416

Chan, H.T., Tam, S.Y.T. and Seo, S.T. (1981). Papaya polygalacturonase and its roles in thermally injured ripening fruit. Journal of Food Science, 46(1), 190197. 2621.1981.tb14561.x

https://doi.org/10.1111/j.1365-

Chauvin, M.A., Younce, F., Ross, C. and Swanson, B. (2008). Standard scales for crispness, crackliness and crunchiness in dry and wet foods: relationship with acoustical determinations. Journal of Texture Studies, 39(4), 345-368. https://doi.org/10.1111/ j.1745-4603.2008.00147.x

Chiari, B.G., Severi, J.A., de Pauli-Credendio, P.A., de Sylos, C.M., Villegas, W., Correa, M.A. and Isaac, V.L.B. (2012). Assessment of the chemical profile, polyphenol content and antioxidant activity in extracts of Psidium guajava L. fruits. International Journal of Pharmacy and Pharmaceutical Sciences, 4(5), 331-336.

Dang, Z., Feng, H., Gao, A. and Chen, Y. (2017). Effect of internal ethylene and 1-methylcyclopropene on ethylene metabolism and membrane lipid peroxidation in papaya fruit. Agricultural Science and Technology, 18(12), 2232-2235.

Del Valle, M.S. (1974). Physiological bases of endogenous brown spot development in pineapple. College, Laguna, Philippines: University of the Philippines Los Baños, BSc. Thesis.

Gill, K.S. (2016). Guavas. In Caballero, B., Finglas, P.M. and Toldra, F. (Eds). Encyclopedia of Food and Health, p. 270-277. Oxford: Academic Press. https:// doi.org/10.1016/B978-0-12-384947-2.00363-9

Hofman, P.J., Jobin-Decor, M., Meiburg, G.F., Macnish, A.J. and Joyce, D.C. (2001). Ripening and quality responses of avocado, custard apple, mango and papaya fruit to 1-methylcyclopropene. Australian Journal of Experimental Agriculture, 41(4), 567572. https://doi.org/10.1071/EA00152

Huber, D.J. (2008). Suppression of ethylene responses through application of 1-methylcyclopropene: a powerful tool for elucidating ripening and senescence mechanisms in climacteric and nonclimacteric fruits and vegetables. HortScience, 43(1), 106-111. https://doi.org/10.21273/ HORTSCI.43.1.106

Jain, N., Dhawan, K., Malhotra, S. and Singh, R. (2003). 
Biochemistry of fruit ripening of guava (Psidium guajava L.): compositional and enzymatic changes. Plant Foods for Human Nutrition, 58, 309-315. https://doi.org/10.1023/ B:QUAL.0000040285.50062.4b

Liu, R., Lai, T., Xu, Y. and Tian, S. (2013). Changes in physiology and quality of Laiyang pear in long time storage. Scientia Horticulturae, 150, 31-36. https:// doi.org/10.1016/j.scienta.2012.10.017

Lurie, S. (2007). 1-MCP in post-harvest: physiological mechanisms of action and applications. Fresh Produce, 1(1), 4-15.

Magarro, A.B. (2018). Identification and characterization of fungi causing diseases of guava (Psidium guajava L.) fruit from Tupi, South Cotabato, Philippines. College, Laguna, Philippines: University of the Philippines Los Baños., BSc. Thesis.

Mamede, A.M.G., Barboza, H.T.G., Soares, A.G., Neves, A.C.V. and de Oliveira Fonseca, M.J. (2016). Postharvest physiology and technology for fresh guavas. In Todorov, S.D. and Bogsan, C.S. (Eds). Tropical Fruits - From Cultivation to Consumption and Health Benefits: Guava and Mango, p. 91-108. New York: Nova Science Publishers Inc.

Manenoi, A., Bayogan, E.R.V., Thurndee, S. and Paull, R.E. (2007). Utility of 1-methylcyclopropene as a papaya postharvest treatment. Postharvest Biology and Technology, 44(1), 55-62. https:// doi.org/10.1016/j.postharvbio.2006.11.005

Mitra, S.K., Devi, H.L. and Chakraborty, I. (2012). Recent development in postharvest physiology and storage of guava. Acta Horticulturae, 959, 89-95 https://doi.org/10.17660/ActaHortic.2012.959.10

Porat, R., Weiss B., Zipori I. and Dag, A. (2009). Postharvest longevity and responsiveness of guava varieties with distinctive climacteric behaviors to 1methylcyclopropene. HortTechnology, 19(3), 580585. https://doi.org/10.21273/HORTSCI.19.3.580

Ranganna, S. (1986). Handbook of analysis and quality control for fruit and vegetable products. p. 190-210. New Delhi, India: Tata McGraw-Hill Publishing Company Ltd.

Singh, S.P. (2010). Prospective and retrospective approaches to postharvest quality management of fresh guava (Psidium guajava L.) fruit in the supply chain. Fresh Produce, 4(1), 36-48.

Singh, S.P. and Pal, R.K. (2008). Response of climacteric-type guava (Psidium guajava L.) to postharvest treatment with 1-MCP. Postharvest Biology and Technology, 47, 307-314. https:// doi.org/10.1016/j.postharvbio.2007.08.010

Sisler, E.C. and Serek, M. (2003). Compounds interacting with the ethylene receptor in plants. Plant Biology, 5(5), 473-480. https://doi.org/10.1055/s2003-44782

Turnos, N.A. (1993). Chilling injury in stored eggplant fruits of different maturities. College, Laguna, Philippines: University of the Philippines Los Baños, $\mathrm{PhD}$. Dissertation.

Wang, J.W., Zhou, X., Zhou, Q., Liu, Z.Y., Sheng, L., Long, W., Cheng, S.C. and Ji, S.J. (2017). Proteomic analysis of peel browning in 'Nangou' pears after low temperature storage. Journal of the Science of Food and Agriculture, 97(8), 2460-2467. https:// doi.org/10.1002/jsfa.8060

Watkins, C.B. (2008). Overview of 1methylcyclopropene trials and uses for edible horticultural crops. HortScience, 43(1), 86-94. https://doi.org/10.21273/HORTSCI.43.1.86

Watkins, C.B. and Nock, J.F. (2012). Rapid 1methycyclopropene (1-MCP) and delayed controlled atmosphere storage of apples. Postharvest Biology and Technology, 69, 24-31. https://doi.org/10.1016/ j.postharvbio.2012.02.010

Zhang, Y.L. and Zhang, R.G. (2008). Study on the mechanism of browning of pomegranate (Punica granatum L. cv. Ganesh) peel in different storage conditions. Agricultural Sciences in China, 7(1), 6573. https://doi.org/10.1016/S1671-2927(08)60023-1

Zhu, X., Shen, L., Fu, D., Si, Z., Wu, B., Chen, W. and Li, X. (2015). Effects of the combination of 1-MCP and ethylene on the ripening of harvested banana fruit. Postharvest Biology and Technology, 107, 2332. https://doi.org/10.1016/ 